\title{
Analisis Kemampuan Komunikasi Matematis dalam Meningkatkan Hasil Belajar Mahasiswa pada Pembelaran Online Matematika Kimia
}

\author{
Nidia Winda Sari ${ }^{1}$, Mirna Nurlaela Dewi ${ }^{2}$, Hajia Rina Kartini ${ }^{3}$ \\ 1,2,3 Program Studi Pendidikan Matematika Fakultas Tarbiyah dan Keguruan \\ UIN Sunan Gunung Djati Bandung \\ Jl. Soekarno Hatta, Cimincrang, Gedebage, Bandung 106294 \\ ${ }^{1}$ e-mail: nidiawindasari@gmail.com Telp.: +6285353147427
}

\begin{abstract}
The purpose of this study is to analyze whether mathematical communication skills can improve student learning outcomes in online chemistry mathematics learning. This type of research is quantitative descriptive research. The population of this research is all chemistry education students in the second semester at Islamic State University of Sunan Gunung Djati Bandung 2019/2020. The sample of this research is the second semester students of chemistry education class B in Islamic State University of Sunan Gunung Djati Bandung 2019/2020. Data collection techniques using a questionnaire. This study uses the pearson bivariate test. The research results show that there is no significant effect between mathematical communication skills on student learning outcomes, so that the higher or lower mathematical communication skills do not affect the learning outcomes of Chemistry Education students in Mathematics Chemistry Mathematics at online learning.
\end{abstract}

Keyword: learning outcomes; mathematical communication skills; online learning

\begin{abstract}
Abstrak
Tujuan penelitian ini adalah untuk menganalisis apakah kemampuan komunikasi matematis dapat meningkatkan hasil belajar mahasiswa pada pembelajaran online matematika kimia.Jenis penelitian ini adalah penelitian deskriptif kuantitatif. Populasi penelitian ini adalah seluruh mahasiswa Pendidikan Kimia semester dua Universitas Islam Negeri Sunan Gunung Djati Bandung tahun ajaran 2019/2020. Sampel penelitian ini adalah mahasiswa kelas B Pendidikan Kimia semester dua Universitas Islam Negeri Sunan Gunung Djati Bandung tahun ajaran 2019/2020. Teknik pengumpulan data dengan menggunakan kuisioner atau angket. Penelitian ini menggunakan uji korelasi Bivariate Pearson. Hasil penelitian menujukkan bahwa tidak ada pengaruh yang signifikan antara kemampuan komunikasi matematis terhadap hasil belajar mahasiswa, sehingga semakin tinggi atau rendahnya kemampuan komunikasi matematis tidak mempengaruhi hasil belajar mahasiswa Pendidikan Kimia pada matakuliah Matematika Kimia pada pembelajaran online.
\end{abstract}

Kata kunci: hasil belajar; kemampuan komunikasi matematis; pembelajaran online 


\section{PENDAHULUAN}

Pandemi covid-19 saat ini telah menyerang dunia, salah satu dampaknya terhadap pendidikan yaitu pelaksanaan pembelajaran harus dilaksakan dalam jaringan dengan kata lain pembelajaran secara online. Hal ini berdasarkan Surat Edaran Nomor 36962/MPK.A/HK/2020 tentang pembelajaran secara daring dan bekerja dari rumah dalam rangka pencegahan penyebaran covid-19 yang ditandatangani oleh menteri pedidikan dan kebudayaan Nadiem Makarim pada selasa (17/3/2020) salah satu isi dari surat tersebut "memberlakukan pembelajaran secara daring dari rumah bagi siswa dan mahasiswa". Pembelajaran online merupakan cara supaya mahasiswa tetap belajar meskipun di rumah. Menurut Tantri (2018:29), keberhasilan pembelajaran online dipengaruhi oleh kehadiran sosial seperti adanya interaksi pengajar dan siswa juga siswa merasa nyaman saat belajar online. Oleh karena itu siswa harus selalu aktif saat pembelajaran online berlangsung.

Karwati (2014:53) mengungkapkan hasil penelitiannya bahwa pembelajaran secara online berada dalam kategori yang tinggi, sementara kualitas pembelajaran berada dalam kategori cukup, pembelajaran online pun memberi pengaruh yang positif dan signifikan terhadap kualitas pembelajaran di Fakultas Keguruan dan Ilmu Pendidikan (FKIP). Namun Chairunnisa (2012:25) mengungkapkan bahwa pembelajaran online tidak terlihat pengaruh yang signifikan terhadap hasil belajar mahasiswa. Santoso (2011:cxii) dalam tesisnya menyarankan bahwa dosen menggunakan media online dalam pembelajaran. Begitupun dalam mata kuliah matematika kimia yang sangat dibutuhkan penjelasan dari dosen yang bersangkutan. Alwathoni (2015:385) menjelaskan bahawa dalam materi asam basa untuk menentukan $\mathrm{pH}$ suatu larutan, dibutuhkan kemampuan komunikasi matematis siswa untuk memahami konsep dan memecahkan masalah hitungan berkaitan dengan istilah matematis, simbol, lambang dan persamaan matematis dalam kimia untuk menjelaskan operasi, konsep dan proses kimia. Dalam mata kuliah matematika kimia dibutuhkan kemampuan komunikasi matematis sebagaimana menurut National Council of Teachers of Mathematics (NCTM, 1998:4), salah satu standar kemampuan matematis yaitu kemampuan komunikasi matematis. Menurut Gordah dan Nurmaningsih (2015:205) kemampuan komunikasi matematis mahasiswa tergolong sangat kurang atau gagal. Sehingga kemampuan komunikasi matematis harus terus ditingkatkan sebagaimana dalam hasil penelitiannya Annisa (2016:105) mengungkapkan bahwa komunikasi matematis mahasiswa perlu ditingkatkan. Menurut Siregar (2018:12), kemampuan komunikasi matematis terdiri dari komunikasi lisan dan komunikasi tulisan. Menurutnya komunikasi lisan berupa menjelaskan dan diskusi sedangkan komunikasi tulisan seperti mahasiswa dapat menuangkan ide matematika melalui tabel, grafik atau gambar, persamaan, atau dengan bahasa siswa sendiri. Menurut Nurhikmayati (2017:78) hasil belajar mahasiswa pada mata kuliah matematika dasar masih sangat rendah sehingga hasil belajar mahasiswa harus selalu ditingkatkan. Menurut Eka, Tuti dan Rizmahardian (2017:170), pembelajaran kimia banyak menggunakan perhitungan yang tentunya sangat berkaitan dengan matematika yang merupakan ilmu dasar dalam menghitung

Berdasarkan pemaparan yang telah dikemukakan, dapat disimpulkan bahwa kemampuan komunikasi matematis sangat penting dimiliki dan juga dengan diharuskannya pembelajaran online mahasiswa pun harus selalu aktif belajar sehingga dapat meningkatkan hasil belajarnya. Oleh karena itu peneliti ingin mengetahui dan menganalisis apakah kemampuan komunikasi matematis dapat meningkatkan hasil belajar mahasiswa pada pembelajaran online matematika kimia sehingga mahasiswa 
dapat melatih kemampuan komunikasi matematisnya meskipun dalam pembelajaran online.

\section{METODE}

Dalam penelitian ini pendekatan yang dilakukan adalah pendekatan deskriptif kuantitatif yang bertujuan untuk menggambarkan secara sistematis mengenai kemampuan komunikasi matematis mahasiswa pada mata kuliah matematika kimia yang dilaksanakan tanggal 30 Maret 2020 kepada 35 mahasiswa Pendidikan Kimia semester dua kelas B tahun ajaran 2019/2020.

Terdapat dua variabel dalam penelitian ini yaitu variabel bebas dan variabel terikat. Variabel bebas adalah variabel yang menjadi sebab timbulnya atau berubahnya variabel terikat (yang mempengaruhi), dalam penelitian ini ialah kemampuan komunikasi matematis yang disimbolkan dengan x. Sedangkan variabel terikat merupakan variabel yang dipengaruhi atau yang menjadi akibat karena adanya variabel bebas, dalam penelitian ini ialah hasil belajar matematika kimia yang disimbolkan dengan y (Sugiyono, 2012, hal. 59).

Teknik pengumpulan data pada penelitian ini adalah menggunakan kuisioner atau angket, pengumpulan data dilakukan dengan cara memberi seperangkat pertanyaan tertulis kepada responden untuk dijawab (Sugiyono, 2012, hal. 199). Dalam penelitian ini, kuesioner atau angket menggunakan skala sikap modal Likert (Sugiyono, 2012, hal. 134).Instrumen penelitian adalah suatu alat yang digunakan dalam mengukur fenomena alam maupun sosial yang diamati (Sugiyono, 2012, hal. 148).

Alat ukur atau instrumen yang baik harus memenuhi dua syarat yaitu validitas dan reliabilitas. Suatu alat ukur yang tidak reliabel atau valid akan menghasilkan kesimpulan yang kurang sesuai dengan yang seharusnya, sehingga dapat menghasilkan informasi yang keliru (Siyoto \& Sodik, 2015, hal. 84).

Alat ukur yang digunakan adalah berupa angket atau kuisioner, dengan alat pengukuran yaitu Skala likert yang terdiri dari 11 pertanyaan, 5 pertanyaan positif dan 6 pertanyaan negatif, setiap pertanyaan dilengkapi dengan 4 pilihan pertanyaan yaitu sangat setuju SS setuju S tidak setuju TTS dan sangat tidak setuju STS.

Tabel 1. Skor pada Skala Likert

\begin{tabular}{ccccc}
\hline \multirow{2}{*}{ Jenis Pertanyaan } & \multicolumn{4}{c}{ Skor } \\
\cline { 2 - 5 } & SS & S & TS & STS \\
\hline Positif & 4 & 3 & 2 & 1 \\
\hline Negatif & 1 & 2 & 3 & 4 \\
\hline
\end{tabular}

Penelitian ini menggunakan uji korelasi Bivariate Pearson untuk menentukan pengaruh antara kemampuan komunikasi matematis terhadap hasil belajar mahasiswa.

\section{HASIL DAN PEMBAHASAN}

Data kemampuan komunikasi matematis mahasiswa diambil dengan cara memberikan angket kepada mahasiswa pendidikan kimia semester 2 kelas B UIN Sunan Gunung Djati Bandung tahun ajaran 2019/2020 yaitu sebanyak 35 mahasiswa. Angket terdiri dari 11 pernyataan untuk mengukur kemampuan komunikasi matematis mahasiswa terdiri dari 5 pernyataan positif dan 6 pernyataan negatif. 3 soal untuk 
mengukur hasil belajar siswa dan 1 pertanyaan pendapat mahasiswa mengenai aplikasi yang sesuai diterapkan dalam pembelajaran daring.

Sebelum dilakukan analisis data, peneliti terlebih dahulu melakukan uji validitas dan reliabilitas data untuk mengetahui layak atau tidaknya instrumen yang digunakan. Peneliti melakukan uji validitas dan reliabilitas instrumen menggunakan bantuan aplikasi SPSS dan diperoleh data seperti pada Tabel 2 berikut.

Tabel 2. Uji Validitas Data

\begin{tabular}{ccccc}
\hline \multicolumn{5}{c}{ Pernyataan Positif } \\
\hline \multirow{2}{*}{ Butir } & Sig. & $\begin{array}{c}\text { Alpha } \\
(\alpha)\end{array}$ & Kriteria & Kesimpulan \\
\hline 4 & 0,423 & 0,05 & Tidak Valid & Tidak Digunakan \\
\hline 7 & 0,000 & 0,05 & Valid & Digunakan \\
\hline 8 & 0,000 & 0,05 & Valid & Digunakan \\
\hline 9 & 0,000 & 0,05 & Valid & Digunakan \\
\hline 11 & 0,000 & 0,05 & Valid & Digunakan \\
\hline \multicolumn{5}{c}{ Pernyataan Negatif } \\
\hline Butir & \multirow{5}{*}{ Sig. } & $\begin{array}{c}\text { Alpha } \\
(\alpha)\end{array}$ & Kriteria & Kesimpulan \\
\hline 1 & 0,026 & 0,05 & Valid & Digunakan \\
\hline 2 & 0,000 & 0,05 & Valid & Digunakan \\
\hline 3 & 0,000 & 0,05 & Valid & Digunakan \\
\hline 5 & 0,000 & 0,05 & Valid & Digunakan \\
\hline 6 & 0,000 & 0,05 & Valid & Digunakan \\
\hline 10 & 0,000 & 0,05 & Valid & Digunakan \\
\hline
\end{tabular}

Interpretasi uji validitas dapat dilihat melalui nilai signifikansi.Apabila nilai signifikansi $>0,05$ maka dapat dikatakan suatu pernyataan tersebut homogeny. Bedasarkan Tabel 2, hasil dari uji validitas menyatakan bahwa hanya terdapat 1 pernyataan yang tidak valid.Artinya 90,9\% pernyataan dapat digunan untuk menguji kemampuan komunikasi siswa.Sebuah tes dikatakaan reliable apabila hasil-hasil tes yang dilakukan menunjukan ketetapan.Setelah dilakukan perhitungan reliabilitas menggunakan bantuan SPSS terhadap data positif diperoleh Cronbach Alpha data positifsebesar 0,498. Karena 0,498 berada pada rentang $0,40 \leq r<0,60$, sehingga tes uji coba data positif memiliki reliabilitas cukup dan Alpha Cronbach data positif sebesar 0,700 berada dalam rentang $0,60 \leq r<0,80$, maka tes uji coba data negatif memiliki reliabilitas tinggi.

Hasil kemampuan komunikasi matematis mahasiswa diperoleh dari hasil analisis angket dapat dilihat pada Tabel 3.

Tabel 3. Analisis Angket Kemampuan Komunikasi Matematis Pembelajaran Online

\begin{tabular}{cccc}
\hline No & Nilai Angket & Frekuensi & Persentase \\
\hline 1 & $57-63$ & 5 & $14,29 \%$ \\
\hline 2 & $64-70$ & 19 & $54,29 \%$ \\
\hline 3 & $71-77$ & 9 & $25,71 \%$ \\
\hline 4 & $78-84$ & 2 & $5,71 \%$ \\
\hline & Total & 35 & $100 \%$ \\
\hline
\end{tabular}


Berdasarkan Tabel 3, hasil distribusi frekuensi angket kemampuan komunikasi matematis mahasiswa diperoleh skor tertinggi yaitu sebesar 84,09 dan terendah sebesar 56,82 . Untuk kemampuan komunikasi matematis mahasiswa pendidikan kimia kelas B tahun ajaran 2019/2020 tergolong cukup dan jika dipersentasekan yaitu sebesar 68,90\%. Hasil belajar matematika kimia mahasiswa dalam pembelajaran online diperoleh dari hasil tes mahasiswa pendidikan kimia kelas B semester dua tahun ajaran 2019/2020 yang disajikan pada Tabel 4.

Tabel 4. Hasil Belajar Siswa

\begin{tabular}{cccc}
\hline No & Nilai Tes & Frekuensi & Persentase \\
\hline 1 & $0-24$ & 8 & $22,86 \%$ \\
\hline 2 & $25-49$ & 10 & $28,57 \%$ \\
\hline 3 & $50-74$ & 13 & $37,14 \%$ \\
\hline 4 & $75-100$ & 4 & $11,33 \%$ \\
\hline & Total & 35 & $100 \%$ \\
\hline
\end{tabular}

Pada Tabel 4 menunjukan bahwa nilai tes tertinggi sebesar 100 dan nilai terendah sebesar 0 , dengan rata-rata nilai sebesar 45,71. Smirrnof).

Adapun hasil uji normalitas dapat dilihat pada Tabel 5 (Tabel Kolmogorof-

Tabel 5. Uji Normalitas Data

\begin{tabular}{|c|c|c|c|}
\hline \multicolumn{4}{|c|}{ One-Sample Kolmogorov-Smirnov Test } \\
\hline & & & $\begin{array}{c}\text { Unstandar } \\
\text { dized } \\
\text { Residual }\end{array}$ \\
\hline \multicolumn{3}{|l|}{$\mathrm{N}$} & 35 \\
\hline \multirow{3}{*}{\multicolumn{2}{|c|}{ Normal Parameters ${ }^{a, b}$}} & Mean & .0000000 \\
\hline & & Std. Deviation & 32.26625 \\
\hline & & & 958 \\
\hline \multirow{3}{*}{\multicolumn{2}{|c|}{ Most Extreme Differences }} & Absolute & .197 \\
\hline & & Positive & .119 \\
\hline & & Negative & -.197 \\
\hline \multicolumn{3}{|c|}{ Test Statistic } & .197 \\
\hline \multicolumn{3}{|c|}{ Asymp. Sig. (2-tailed) } & $.001^{\mathrm{c}}$ \\
\hline \multirow{3}{*}{$\begin{array}{l}\text { Monte } \\
\text { Carlo Sig. } \\
\text { (2-tailed) }\end{array}$} & \multirow{3}{*}{$\begin{array}{l}\text { Sig. } \\
\text { 99\% Confidence Interval }\end{array}$} & & $.120^{\mathrm{d}}$ \\
\hline & & $\begin{array}{l}\text { Lower } \\
\text { Bound }\end{array}$ & .112 \\
\hline & & $\begin{array}{l}\text { Upper } \\
\text { Bound }\end{array}$ & .128 \\
\hline
\end{tabular}

Berdasarkan Tabel 5 tersebut menunjukan bahwa hasil kemampuan komunikasi matematis mahasiswa sebelum dan sesudah pembelajaran online merupakan data yang berdistribusi normal. 
Tabel 6. Uji Linieritas

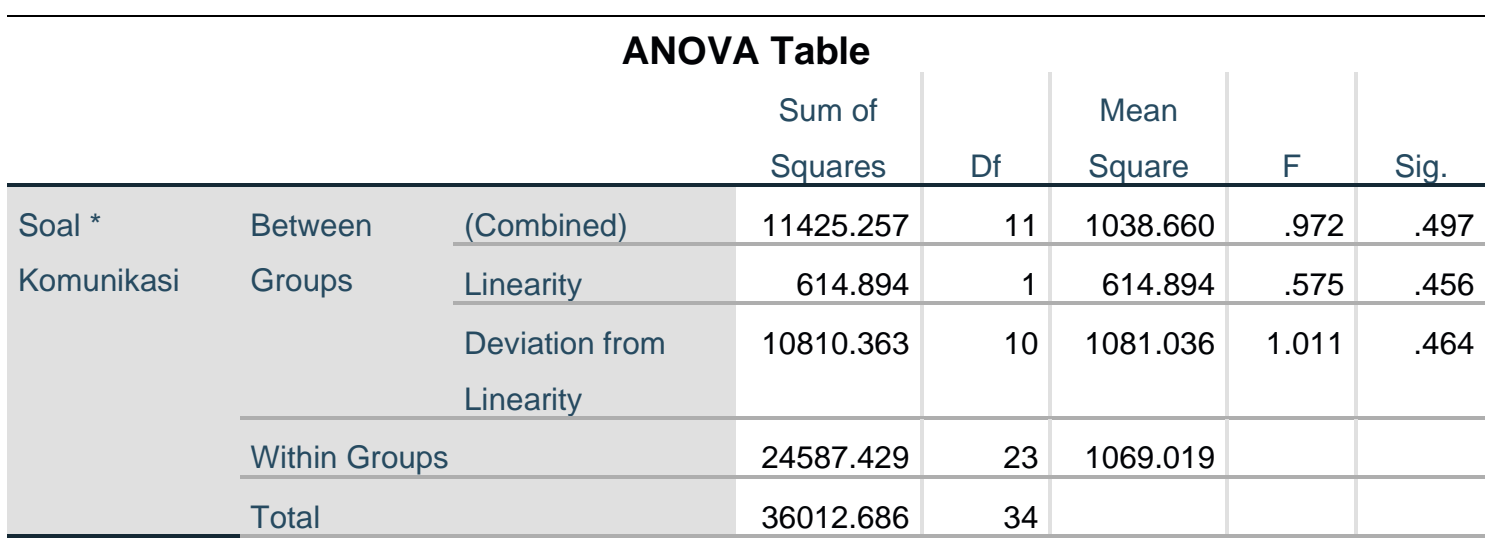

Selain itu, peneliti juga melakukan uji linieritas menggunakan SPSS terdapat padatabel Anova yang dapat dilihat pada tabel 6. Tabel tersebut menunjukan nilai signifikansi 0,454>0,05 maka dapat disimpulkan data kemampuan komunikasi matematis (variabel $\mathrm{x}$ ) dengan hasil belajar matematika kimia (variabel y) linier.

Uji korelasi untuk menentukan pengaruh kemampuan komunikasi matematis terhadap hasil belajar mahasiswa pada pembelajaran online dapat dilihat pada Tabel 7 .

Tabel 7. Uji Korelasi

\section{Correlations}

\begin{tabular}{|c|c|c|c|}
\hline & & Komunikasi & Hasil \\
\hline \multirow[t]{4}{*}{ Komunikasi } & Pearson & 1 & -.131 \\
\hline & Correlation & & \\
\hline & Sig. (2-tailed) & & .454 \\
\hline & $\mathrm{N}$ & 35 & 35 \\
\hline \multirow[t]{4}{*}{ Soal } & Pearson & -.131 & 1 \\
\hline & Correlation & & \\
\hline & Sig. (2-tailed) & .454 & \\
\hline & $\mathrm{N}$ & 35 & 35 \\
\hline
\end{tabular}

Berdasarkan Tabel 7, hasil uji korelasi Bivariate Pearson diperoleh nilai Sig.(2tailed) > Alpha $(0,05)$ artinya tidak ada pengaruh yang signifikan antara kemampuan komunikasi matematis terhadap hasil belajar mahasiswa pendidikan kimia kelas B semester 2 UIN Sunan Gunung Djati Bandung tahun ajaran 2019/2020. Sehingga semakin tinggi ataupun rendah kemampuan komunikasi matematis tidak mempengaruhi hasil belajar mahasiswa pendidikan kimia pada matakuliah matematika kimia pembelajaran online.

Peneliti merangkum pendapat mahasiswa mengenai aplikasi yang mudah dan efektif digunakan dalam pembelajaran online, sehingga diperoleh data bahwa $28,57 \%$ mahasiswa memilih aplikasi Hangout Meet, 22,86 \% aplikasi Zoom, 17,14\% WhatsApp, 
8,57\% memilih Google Classroom, $11,43 \%$ memilih menggunakan Video Pembelajarandan $8,57 \%$ mahasiswa tidak memilih aplikasi apapapun.

Pembelajaran online akan berjalan dengan baik apabilaakses internet bisa menjangkau ke seluruh daerah, sehingga pendidikan secara online dapat dinikmati seluruh masyarakat tanpa terkecuali. Karena sebagian besar kendala dari penggunaan aplikasi pembelajaran online tersebut adalah masalah jaringan, biaya kuota yang mahal, sulit memahami materi yang disampaikan dosen, dan adanya ancaman dari hacker pada aplikasi tersebut (Novita, 2020:9-10).

Nilai probabilitas interaksi kemampuan komunikasi matematis dengan hasil belajar siswa berbeda pada Tabel 7 adalah 0,454 >0,05, sehingga hipotesis nol diterima. Hal ini berarti "tidak terdapat interaksi antara kemampuan komunikasi matematis pembelajaran online terhadap hasil belajar mahasiswa pada matakuliah matematika kimia". Hal ini sesuai dengan Kerlinger yang dikutip oleh Mustapa (2014:354) menyatakan bahwa interaksi merupakan variasi dua variabel bebas atau lebih dalam mempengaruhi variabel terikat. Hasil tersebut menunjukan bahwa hasil belajar mahasiswa tidak ditentukan oleh pencapaian kemampuan komunikasi matematis mahasiswa pada mata kuliah matematika kimia.

Kondisi tersebut terjadi disebabkan terjadinya kelemahan dalam pemberian perlakuan khususnya pada proses interaksi pada pembelajaran online baik sesama pelajar maupun antara pelajar dan materi pembelajaran. Hal ini juga disebabkan oleh beberapa faktor diantaranya kebiasaan mahasiswa pada saat proses pembelajaran. Pada umumnya mahasiswa hanya mendengarkan saat pembelajaran offline berlangsung, sedangkan pada saat pembelajaran online terdapat beberapa mata kuliah yang materinya memerlukan penjelasan langsung sehingga memahami materi menjadi tantangan bagi mahasiswa (Jamaluddin, 2020:4).

\section{SIMPULAN}

Berdasarkan data hasil penelitian tentang efektivitas pembelajaran online terhadap kemampuan komunikasi matematis dan pengaruhnya terhadap hasil belajar mahasiswa Pendidikan Kimia kelas B semester dua tahun ajaran 2019/2020 pada mata kuliah matematika kimia dapat disimpulkan bahwa hasil penelitian kemampuan komunikasi matematis menggunakan angket diuji dengan uji validitas diperoleh 10 pernyataan valid, berdasarkan uji reliabilitas dengan teknik Alpha Crosbach diperoleh nilai reabilitas data positif sebesar 0,498 yang berarti memiliki reliabilitas tinggi dan memperoleh rata-rata sebesar 68,57 serta rata-rata data hasil belajar yaitu 45, 71; hasil perhitungan dengan SPSS memiliki nilai signifikansi sebesar 0,112 dengan uji normalitas berdistribusi normal dan uji linieritas memiliki nilai signifikansi 0,454 > 0,05 sehingga diperoleh data yang linier; dan hasil uji korelasi bivariate person diperoleh nilai Sig.(2-tailed)>Alpha(0,05) menunjukkan bahwa tidak ada pengaruh yang signifikan antara kemampuan komunikasi matematis terhadap hasil belajar mahasiswa Pendidikan Kimia kelas B semester 2 tahun ajaran 2019/2020 pada pembelajaran online matematika kimia.

\section{REFERENSI}

Alwathoni, M. (2015). Peningkatan Aktivitas Belajar Dan Kemampuan Komunikasi Matematika Untuk Kimia Pokok Bahasan Larutan Buffer dan Hidrolisis Garam dengan Model Pembelajaran Learning Cycle 5E Pada Kelas XI IPA MAN Gubug Kabupaten Grobogan Tahun Pembelajaran 2014/2015. Prosiding Seminar Nasional Pendidikan Sains (SNPS), 385-393. 
Annisa, C. (2016). Analisis Kemampuan Komunikasi Matematis Mahasiswa Dengan Implementasi RME. Jurnal Pendidikan Dan Pembelajaran Matematika (JP2M), 2(1), 105-112.

http://dx.doi.org/10.29100/jp2m.v2i1.220

Gordah, E. K., \& Nurmaningsih. (2015). Analisis Kemampuan Komunikasi Matematis Mahasiswa pada Materi Kuliah Geometri Analitik di Program Studi Pendidikan Matematika IKIP PGRI Pontianak. Jurnal Pendidikan Informatika Dan Sains, 4(2), 195-206.

http://dx.doi.org/10.31571/saintek.v4i2.70

Jamaluddin, D., \& Teti dkk. (2020). Pembelajaran Daring Masa Pandemik Covid-19 Pada Calon Guru: Hambatan, Solusi dan Proyeksi. Lembaga Penelitian dan Pengabdian Kepada Masyarakat UIN Sunan Gunung Djati Bandung,1-10.

Kurniawati, E. G., \& Tuti, dkk (2017). Deskripsi Kemampuan Matematika Dan Korelasinya Dengan Hasil Belajar Siswa Pada Mata Pelajaran Kimia Kelas X MIPA SMA Negeri. 4 Pontianak. Ar-Razi Jurnal Ilmiah, 5(2), 169-180. http://dx.doi.org/10.29406/arz.v5i2.630

NCTM. (1998). Pssm. Journal of Equine Veterinary Science, 18(11), 719. https://doi.org/10.1016/s0737-0806(98)80482-6

Karwati, E. (2014). Pengaruh Pembelajaran Elektronik (E-Learning) terhadap Mutu Belajar Mahasiswa. Jurnal Penelitian Komunikasi, 17(1), 41-54. https://doi.org/10.20422/jpk.v17i1.5

Mustapa, K. (2014). Pengaruh Strategi Pembelajaran Terhadap Kemampuan Berpikir Tingkat Tinggi. Jurnal Pendidikan Humaniora, 2(4), 348-357.

Chairunnisa, L (2012). Pengaruh Pembelajaran E-Learning Terhadap Hasil Belajar Mata Kuliah Statistics Mahasiswa Tadris Bahasa Inggris Fakultas Tarbiyah IAIN Walisongo. Jurnal Phenomenon, 2(1), 7-27.

http://dx.doi.org/10.21580/phen.2012.2.1.416

Novita, D. (2020). Plus Minus Penggunaan Aplikasi-Aplikasi Pembelajaran Daring Selama Pandemi Covid-19. Unimed Medan ,1-11. https://www.researchgate.net/publication/341830562

Nurhikmayati, I. (2017). Analisis kesulitan belajar mahasiswa pada matakuliah matematika dasar. Theorems, 2(1), 74-85.

http://jurnal.unma.ac.id/index.php/th/article/view/576

Santoso, E. (2011). Pengaruh Pembelajaran Online TerhadapPrestasi Belajar Kimia Ditinjau dari Kemampuan Awal Siswa. Tesis.

Siregar, N. F. (2018). Komunikasi Matematis Dalam Pembelajaran Matematika. Logaritma: Jurnal Ilmu-Ilmu Pendidikan Dan Sains, 6(02), 74. https://doi.org/10.24952/logaritma.v6i02.1275 
Jurnal Pendidikan Matematika Universitas Lampung, Vol. 8, No. 2, 2020

Siyoto, S., \& Sodik, A. (2015). Dasar Metodologi Penelitian. Yogyakarta: Literasi Media Publishing.

Sugiyono. (2012). Metode Penelitian Kuantitatif, Kualitatif, dan R\&D. Bandung: Alfabeta.

Tantri, N. G. (2018). Kehadiran Sosial dalam Pembelajaran Daring Berdasarkan Sudut Pandang Pembelajar Pendidikan Terbuka dan Jarak Jauh. Jurnal Pendidikan Terbuka Dand Jarak Jauh, 19(1), 20-30.

https://doi.org/10.33830/ptji.v19i1.310.2018 